\title{
Inquiry-Based Learning in History
}

\author{
Andreas Bihrer, Stephan Bruhn, and Fiona Fritz
}

The goal of the following article is to develop the prospects for the concept of inquirybased learning in the subject of history. At the start of the article, the current state of the research will be outlined and a separate understanding of the underlying term will be discussed. Selected projects and fields for inquiry-based learning are presented before the article concludes with the development of new perspectives.

\subsection{Introduction and State of the Research}

Forms and elements of inquiry-based learning are indeed used in the field of history at German institutions of higher learning, but so far only a few didactic reflections or programmatic contributions have been formulated: For example, bibliographic databases such as FIS Bildung and ERIC cite neither cross-sectional studies in current anthologies (e.g. Reiber 2007; Huber et al. 2009) nor individual publications; only a few project ideas are shown (e.g. Bihrer 2009; Battaglia and Bihrer 2010; Bihrer et al. 2010; Brauch and Bihrer 2011). This may be due to the state of the research on inquiry-based learning in

\footnotetext{
A. Bihrer, Prof. Dr. $(\bowtie) \cdot$ S. Bruhn, Dr.

Christian-Albrechts-Universität zu Kiel, Historisches Seminar, Professur für Geschichte des frühen und hohen Mittelalters sowie für Historische Grundwissenschaften,

Kiel, Germany

e-mail: abihrer@email.uni-kiel.de; bruhn@histosem.uni-kiel.de

F. Fritz

Körber-Stiftung, Arbeitsbereich "Geschichte und Politik", Programm-Managerin EUSTORY; History Campus, Hamburg, Germany

e-mail: fritz@koerber-stiftung.de
} 
general, since its conceptualization is still in its infancy (Huber 2014a), and the international technical debate has not led to any clearly defined concepts, even in the Anglosphere (Kossek 2009). Although descriptions of best practice examples, generalized pedagogical concepts, and ideas for university-based guiding principles have been published, it is often difficult to recognize or process other research in higher education didactics.

Against this background, and taking into consideration the different forms of empowering teaching and learning - which university administrators, in particular, want to label as inquiry-based learning or "research-led learning" due to the current attractiveness of the concept of research - it is also necessary to develop clearer definitions for the science of history and put up more clearly formulated concepts for discussion. Unlike the previous discussion (e.g. Huber 2004, 2014a; Reiber and Tremp 2007), inquiry-based learning should be clearly distinguishable from learning that is oriented towards problems, action or projects; of a genetic or discovering nature; and research-oriented or research-based. In the following, a definition is proposed, according to which the focus is not just on the change in perspective and role of students from learner to researcher - and evaluating this change - and the completion of all steps of a research cycle, as in the previous debate. Rather, two elements of this process should be given special significance There are two decisive factors - firstly the innovative research question developed by the students themselves (Brauch and Bihrer 2015), and secondly not only the generation of new knowledge that is of interest to third parties according to the standards of the subject, but also the presentation of the research results in a forum recognized by the scientific community. From this perspective, the mere creation of a wall news-sheet or a homepage is not enough; rather, the new findings must be addressed to the specialist community and issued in established forms of publication (Bihrer 2009).

\subsection{Basic Conditions}

In Germany, basic university conditions for the subject of history do not differ significantly from the circumstances of other major subjects in the humanities: Immense student demands are faced with low teaching capacities, which results in a poor level of support. As a result, larger projects in accordance with inquiry-based learning are limited. Employment opportunities for instructors in the subject of history are often limited to a few semesters, and (as in other subjects in the humanities) the course of studies is not designed as a narrow-based vocational education, due to the diversity of professional fields already outlined for students. The heterogeneity of students in terms of study progress, abilities or motivation is typical for courses in the field of history, which nevertheless need not be an obstacle to inquiry-based learning, since research assignments can be distributed at different levels within a project group. The greatest percentage of students have chosen the teaching profile for their history studies; the concept of inquiry-based learning is interesting for this circle, not least because this and similar didactic approaches are also being tested and implemented at the school level. Thus, not only a practical course of a 
research cycle, but also engagement with pedagogic and methodological issues is necessary for teaching students. For this purpose, the extension of the previous collaboration with subject didactics and teacher training is of particular importance. In addition, inquirybased learning projects should be pursued in history as an academic discipline, but also in collaboration with non-university institutions such as archives, libraries or research centers.

Over the course of the Bologna Process, the basic conditions in Germany for the study of history have been reformed, as well as for other degree programs. Nevertheless, the central objectives of competence orientation and employability in the revised study regulations have generally been formulated as abstract competencies or judged solely on their usability for work and career. This revision of the examination regulations and study plans, as well as the formulation of module descriptions, has in many cases led to the development of a propaedeutic introductory phase of the course of study that is separated from research. The initial aim in this phase is to impart so-called basic knowledge, which complicates projects according to the stipulations of inquiry-based learning. In addition, modules have often been very narrowly defined, module descriptions established as binding content and didactic guidelines, and the connection of courses over several semesters hindered, which in turn hinders the implementation of projects based on inquiry-based learning. For this reason, at least the combination of previously separate teaching formats would have to be facilitated. In addition, the recognition of suitable forms of examination for inquiry-based learning should be realized (Huber 2009). Finally, in times of an actual or perceived overload on teachers and learners, it is essential that meaningful lesson planning in formats of inquiry-based learning be made possible by clearing out the curricula or reducing exam pressure, and that greater temporal leeway or at least planning certainty be allowed by clearly designating particularly labor-intensive phases.

In order to create better conditions for inquiry-based learning in the study of history, or even to establish the concept as a "curricular principle" (Reiber and Tremp 2007, p. 4), many of these changes can only be achieved through further development of the degree programs - which may, however, be problematic in the post-Bologna era, in which there is growing reform skepticism, in addition to disappointment with and fatigue of reforms. In the case of curricular readjustments, it is always necessary to consider that inquirybased learning projects should not only be integrated at the end of the study course in the form of internships or practical semesters, but should also be implemented in the introductory phase of the course of study (general information about this, Huber 2004; for a course of study in history, Brauch and Bihrer 2015). A thematic approach should apply to all formats; however, that approach should retain a degree of technical specificity in its basic features: It must be possible to connect not only to other seminars, but above all to other institutions of higher learning so that degrees and requirements always remain comparable and, in the event of a change of university, acquired academic achievements can be recognized. The challenges for instructors associated therewith should be addressed through to reflection, evaluation, continuing education, greater networking among lecturers, and higher education didactic professionalization ("Scholarship of Teaching and Learning") 
(Huber 2014b). Before inquiry-based learning can be established as a guiding principle for universities and used meaningfully by universities for profile development, these problems must first be tackled at the subject level.

\subsection{Projects - Mapping and Perspectives}

Although individual approaches to inquiry-based learning have been implemented into teaching and learning research pertaining to history as an academic discipline, this is in no way a systematic implementation or even penetration of the subject culture. In the following, we shall therefore undertake an initial mapping of those concepts of inquiry-based learning that are currently being pursued, planned or discussed in the field of history within higher education instruction in Germany. This overview, which in no way claims to be complete nor sets out to proceed in an exemplary manner, but rather seeks to etch out previously pursued guidelines, also serves as a starting point for a number of considerations of a conceptual nature that make it possible to demonstrate further prospects for history as an academic discipline.

\subsubsection{Practiced Teaching Methods}

In recent years, the demand that the study of history be oriented towards practice and competence has produced a variety of forms and formats, by means of which this reorientation is to be implemented in teaching. In so doing, inquiry-based learning approaches are not infrequently taken into consideration, whether consciously or unconsciously. In addition to the established fields and forums for student research - the qualification theses and colloquia - other concepts, which are also aimed at a non-university public, are being tested, with publication of the results as their goal (at least for some of the concepts): award-winning essay competitions; research studios which bring students into contact with doctoral candidates and post-doctoral researchers within the context of small conferences and workshops; and independently developed study trips that go through all the organizational phases, from ideas concerning fundraising to travel planning and implementation. Furthermore, participation in scholarly book projects (anthologies with student contributions, regional history encyclopedias, editions, etc.), readings before a lay audience (Schöck-Quinteros and Steffen 2013), the conception and implementation of historical tours or exhibitions, memorial work and formats of "re-enactment" or experimental archeology primarily rooted in popular culture should also be mentioned. This cursory listing may already be sufficient to show the wealth of variants that can be found. 


\subsubsection{History and Public Relations - Impetus from Applied History or Public History as well as National and Regional History}

An important impetus for implementing practice-oriented approaches also comes from the field of applied history or public history, a still relatively recent trend in history in Germany, which deals with the public connection to history in all its facets. The growing importance of this sub-area is evident above all in university institutionalization, despite all the conceptual and methodological blurring that still characterizes the field in the Germanspeaking area (Nießer and Tomann 2014; Zündorf 2014). In addition to independent degree programs at the Freie Universität Berlin and the Universities of Mannheim and Bremen, we should mention the "Professur für Angewandte Geschichtswissenschaft Public History" in Heidelberg, and the field of "Public History" in Hamburg. The latter has even replaced the "Allgemeine Berufsqualifizierende Kompetenzen" (general vocationally qualifying competencies) in the Department of History, thereby making the connection to the ideal of employability particularly evident. In terms of implementing inquiry-based learning approaches, the field of applied history/public history is of particular importance, as it places university research and education in direct relationship with public engagement with history, enters into and maintains collaborations with non-university institutions, reveals employment opportunities, and is dedicated to project acquisition. Thus institutional and - above all - subject-specific basic conditions are made available, by means of which the realization of research projects can find a direct and continuous input into teaching in order to support students in their involvement in the professional discourse on history in the long term, beyond the promotion of individual projects or the engagement of individual teachers. In this way, public interest in history is actively used to familiarize students early on with non-university representations and forms of mediation of the historical, and to introduce them to broader contexts, which may include not only the technical activity but also aspects of marketing or presentation skills.

Similar approaches are also being pursued in the departments of regional history, which are already in close contact with non-university institutions due to the orientation of their research field. Projects relating to regional history offer the advantage that they can usually be carried out in direct geographical proximity to the university location, and thus archives, history societies or other cooperation partners can be accessed without much financial or logistical effort. In addition, approaches of inquiry-based learning seem to be more transepochal at the level of regional history than in the area of applied history/public history that has a clear orientation towards contemporary history. However, inquiry-based learning should not be confined to what is assumed to be more familiar and accessible, but rather should encompass all epochs and topics of history. In this way, the heterogeneous interests of the students can be taken into account, even if different implementation options are available or changing methodological concepts may be useful, depending on the epoch. 


\subsubsection{From Theory to Practice: The Auxiliary Sciences of History}

The question of epoch-specific methodology leads to another field which is currently in a position to make an important contribution to the implementation of inquiry-based learning approaches. We are talking about the auxiliary sciences of history, which are traditionally oriented towards the pre-modern age - a curriculum which is not uniformly defined, and which serves to open up the traditional source material in its original form. The auxiliary sciences have been under fire for some years because of their supposedly outmoded nature and their rigid classification system. This is a circumstance that is mainly reflected in the higher education landscape itself, where professorships with a corresponding denomination are often not filled again after being vacated or study programs in this area are being systematically reduced (Kümper 2014, pp. 10-13). On the other hand, it should be noted that working with sources in their original form as well as the analysis of manuscripts, documents, seals or inscriptions is a motivating factor for students that should not be underestimated. Here, history literally becomes "tangible" to them, and this is where the feeling of being able to interact directly with a bygone era and enter uncharted territory arises (Battaglia and Bihrer 2010). It is therefore not necessary to abolish the auxiliary historical sciences, which are still indispensable for sound engagement with all kinds of historical records. Instead, a methodological reorientation is needed, which takes into account changes in the basic conditions of the study of history and at the same time recalls its practical roots. Instead of instruction that is centered on lecturers, which merely aims to familiarize students with the classification system of the auxiliary sciences curriculum based on examples, an application-related, student-centered learning situation must be created which starts with a concrete application, offers selective assistance in the independent development of the material and ideally leads to the development of any transferable and applicable competence. It is only in this way that students become aware of the relevance of their own contribution to historical research to the historical record, thus retaining the motivation inspired by the "aura of the original" (Bihrer 2009, p. 78). Because of this reorientation of instruction, which partially breaks through the existing classification system, the proposal has recently been made to speak of practice-oriented „Materialwissenschaften “(“material sciences,” Kümper 2014) rather than theoretical and abstract auxiliary sciences - an approach that could prove promising in relation to teaching history.

\subsection{Conclusion}

What further perspectives can be formulated at a higher level following this overview? First of all, it should be noted that in all of the approaches and tendencies that have been presented, practice-oriented teaching does not necessarily imply inquiry-based learning. In forms of teaching and projects related to the field of applied history or public history, or as a result of research in regional history, it remains to be seen to what extent research 
processes are not only imitated by students, but also independently realized. So do these courses actually produce student publications that have developed from joint work in the seminar and that are clearly identifiable as individual achievements, finding their way into specialist discourse? It is only when these basic conditions have been met - which is to say the independent formulation of an innovative research question on the one hand, and product orientation on the other - that the buzzword "inquiry-based learning" becomes a viable concept, and imitation becomes serious participation.

In addition, taking into account the growing number of digital publication formats, it is critical to question the extent to which they can actually provide an alternative to "traditional" publication in print. This is because there are still serious reservations in the subject area with regard to online publications, not least because of the lack of quality controls, the abundance of information on the Internet, and the discontinuous management of many websites. Therefore, student contributions to the historical discourse should not be published online in the form of individual attempts, but instead should be linked to institutionalized platforms that are recognized within the subject area and (hence) continuous, that ensure the quality of the contributions, link the different projects with one another and conduct site maintenance in accordance with the requirements of a digital environment. Workspaces for public history (applied history) that already exist or that are in the start-up phase, as well as the relevant specialist portals, lend themselves to this task, since these could meaningfully integrate a component that has been defined in this manner into their public relations work. Ultimately, greater consideration of subject-specific standards can only be achieved through greater financial expenditures and the expansion of the existing personnel structure, so that in the long run, the question will be raised as to whether sustainable digital publishing is less intensive than the "traditional" printed publication formats.

In view of the university-specific basic conditions, it would also be desirable to expand funding opportunities and personnel capacities in order to improve the educator-student ratios in the subject in the long term and ideally to adjust them accordingly in response to the increasing number of students. Although interdisciplinary problems such as insufficient funding and overburdening of higher education structures place enormous limits on inquiry-based learning, in principle they cannot be considered to be arguments against an at least gradual implementation of this learning approach. A complete orientation of historical studies to research-related forms of teaching and learning is neither feasible nor meaningful. Rather, it seems worthwhile to integrate aspects of research activities into traditional teaching formats, for example in the form of smaller research processes that are independently organized by the participants. Furthermore, courses such as those presented could be created at the level of the curricula or through cooperation with external partners as a relief measure in order to create more freedom for students and lecturers alike.

A final point emphasizes the urgent need for further orientation courses in history, which relate individual projects to one another and evaluate them with regard to a subjectspecific methodology - an approach that has yet to be developed. In addition, there is often no clear positioning relative to other forms of empowering learning, not least because of 
the lack of specialized subject matter and methodology. In particular, however, meaningful methods and study grids must be developed, which can then be used to determine the acquisition of competencies by students and the gradual promotion of autonomy within or by courses. The successful publication of research findings is by no means sufficient when speaking of successfully implementing the committed learning objectives of modern universities. Rather, it is necessary to specifically determine the learning successes and learning progress achieve by each individual participant - and at which point in time, and in which way - in the course of the research process, in order to be able to effectively manage the acquisition of skills and to continue to develop existing approaches in a systematic and purposeful manner. This is indispensable, not least in the sense of "broad support," because inquiry-based learning should not be an approach for shaping elitist educational structures. Here, an important impetus could be provided by history didactics, which is often still strongly oriented towards the teaching of history in school and the education of history teachers, in keeping with the requirements primarily directed at it in everyday university life. It is only in this environment that one can find those specialists, who are familiar both with the principles of empirical educational research and with the epistemological maxims of the subject area, and thus have the necessary competence to develop practical inquiry-based learning approaches with reference to history. This is because a sustainable implementation of inquiry-based learning can only come about if there is a change in the teaching culture in the subject, which requires higher education didactic guidance.

\section{References}

Battaglia, S./Bihrer, A. (2010). C 2.16: Vom Frontalunterricht zum forschenden Lernen: Kompetenzorientierung, Individualisierung und Praxisrelevanz in der universitären Lehre. In B. Berendt/H.-P. Voss/J. Wildt (Hrsg.), Neues Handbuch Hochschullehre (Ergänzungslieferung, 41. Band) (S. 1-22). Berlin: Raabe.

Bihrer, A. (2009). Natürlich, eine alte Handschrift... Forschendes Lernen in der Geschichtswissenschaft. In L. Huber/J. Hellmer/F. Schneider (Hrsg.), Forschendes Lernen im Studium: Aktuelle Konzepte und Erfahrungen (S. 70-78). Bielefeld: UniversitätsVerlagWebler.

Bihrer, A./Schiefner, M./Tremp, P. (2010). Forschendes Lernen und Medien: Ein Bespiel aus den Geschichtswissenschaften. In S. Mandel/M. Rutishauser/E. Seiler Schiedt (Hrsg.), Digitale Medien für Lehre und Forschung (Medien in der Wissenschaft, 55. Band) (S. 95-105). Münster u. a.: Waxmann.

Brauch, N./Bihrer, A. (2011). Die »Wikinger« als Lernanlass in der Geschichtslehrerbildung: Theoretische Überlegungen und erste empirische Befunde einer Studie zur Graduierung von Kompetenzen geschichtsdidaktischen Denkens. Zeitschrift für Geschichtsdidaktik, 10, 117-130.

Brauch, N./Bihrer, A. (2015). FOGEL: Forschende Geschichtslehrer/innen. Retrieved 1 April 2015 from https://www.histsem.uni-kiel.de/de/abteilungen/mittelalterliche-geschichteund-historische-hilfswissenschaften/mitarbeiter/prof.\%2D\%2Ddr.-phil.-andreas-bihrer/ forschungsprojekte

Huber, L. (2014a). Forschungsbasiertes, Forschungsorientiertes, Forschendes Lernen: Alles dasselbe? Ein Plädoyer für eine Verständigung über Begriffe und Unterscheidungen im Feld forschungsnahen Lehrens und Lernens. Das Hochschulwesen, 1+2, 22-29. 
Huber, L. (2014b). Scholarship of Teaching and Learning: Konzept, Geschichte, Formen, Entwicklungsaufgaben. In L. Huber/A. Pilniok/R. Sethe/B. Szcyzyrba/M. Vogel (Hrsg.), Forschendes Lehren im eigenen Fach: Scholarship of Teaching and Learning in Beispielen (S. 19-36). Bielefeld: Bertelsmann.

Huber, L. (2004). Forschendes Lernen: 10 Thesen zum Verhältnis von Forschung und Lehre aus der Perspektive des Studiums. Die Hochschule, 13 (2), 29-49.

Huber, L. (2009). Warum Forschendes Lernen nötig und möglich ist. In L. Huber/J. Hellmer/ F. Schneider (Hrsg.), Forschendes Lernen im Studium: Aktuelle Konzepte und Erfahrungen (S. 9-36). Bielefeld: UniversitätsVerlagWebler.

Kossek, B. (2009). Survey: Die forschungsgeleitete Lehre in der internationalen Diskussion. Retrieved 31 March 2015 from https://ctl.univie.ac.at/fileadmin/user_upload/elearning/ Forschungsgeleitete_Lehre_International_090414.pdf

Kümper, H. (2014). Materialwissenschaft Mediävistik: Eine Einführung in die Historischen Hilfswissenschaften. Paderborn: Schöningh.

Nießer, J./Tomann, J. (2014). Einleitung. In J. Nießer/J. Tomann (Hrsg.), Angewandte Geschichte: Neue Perspektiven auf Geschichte in der Öffentlichkeit (S. 7-14). Paderborn: Schöningh.

Reiber, K. (Hrsg.). (2007). Forschendes Lernen als hochschuldidaktisches Prinzip: Grundlegungen und Beispiele (Tübinger Beiträge zur Hochschuldidaktik 3 (1)). Tübingen: Universität. Retrieved 31 March 2015 from https://publikationen.uni-tuebingen.de/xmlui/bitstream/handle/10900/43870/pdf/TBHD\%203-1-2007Reiber.pdf?sequence=1\&isAllowed=y

Reiber, K./Tremp, P. (2007). A 3.6: Eulen nach Athen! Forschendes Lernen als Bildungsprinzip. In B. Berendt/H.-P. Voss/J. Wildt (Hrsg.), Neues Handbuch Hochschullehre (Ergänzungslieferung, 30. Band) (S. 1-14). Berlin: Raabe.

Schöck-Quinteros, E./Steffen, N. (2013). »Aus den Akten auf die Bühne«-Studierende erforschen »Eine Stadt im Krieg «: Ein geschichtswissenschaftliches Crossover-Projekt zwischen Forschung, Lehre und Theater. In L. Huber/M. Kröger/H. Schelhowe (Hrsg.), Forschendes Lernen als Profilmerkmal einer Universität (S. 195-209). Bielefeld: Universitäts VerlagWebler.

Zündorf, I. (2014). Public History und Angewandte Geschichte - Konkurrenten oder Komplizen? In J. Nießer/J. Tomann (Hrsg.), Angewandte Geschichte: Neue Perspektiven auf Geschichte in der Öffentlichkeit (S. 63-76). Paderborn: Ferdinand Schöning.

Open Access This chapter is licensed under the terms of the Creative Commons AttributionNonCommercial-NoDerivatives 4.0 International License (http://creativecommons.org/licenses/bync-nd/4.0/), which permits any noncommercial use, sharing, distribution and reproduction in any medium or format, as long as you give appropriate credit to the original author(s) and the source, provide a link to the Creative Commons licence and indicate if you modified the licensed material. You do not have permission under this license to share adapted material derived from this chapter or parts of it.

The images or other third party material in this chapter are included in the chapter's Creative Commons licence, unless indicated otherwise in a credit line to the material. If material is not included in the chapter's Creative Commons licence and your intended use is not permitted by statutory regulation or exceeds the permitted use, you will need to obtain permission directly from the copyright holder.

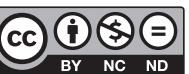

